\title{
LIFE INSURANCE UNDER REFORMING THE PENSION INSURANCE SYSTEM
}

\author{
Ruslana Pikus ${ }^{1}$, Anna Khemii' $^{2}$
}

\begin{abstract}
The purpose of the paper is to generate practical recommendations on the prospects of life insurance development under reforming the pension insurance system in Ukraine. Methodology. In the article, a considerable attention is paid to international experience, the implementation of which is relevant for Ukraine today. In determining the place of life insurance in European pension systems, the experience of Spain and the United Kingdom is considered, which is sufficiently indicative for Ukraine and can serve as a model for reforming the national pension system. Methodological basis of the article are methods of scientific cognition, which enable to expose basic conformities to the law of development of the pension systems in this countries and place of life insurance in them. Such methods are in particular used as: analysis and synthesis - during the study of reforming pension systems, their detailed analysis and definition of their peculiarities; scientific abstraction - with the purpose of forming of theoretical generalizations and conclusions; also, the method of scientific synthesis, forecasting method, econometric modelling for forecasting the development of life insurance in Ukraine up to 2020. Results. The pension insurance system of Ukraine is at the stage of reformation by introducing compulsory accumulation of pension funds and the development of voluntary non-state pension insurance. The main financial intermediaries providing voluntary pension accumulation services in Ukraine are: banks - through the possibility of saving on retirement deposits, insurance companies - through life insurance products, and non-state pension funds (NPFs) through the voluntary participation of citizens in such funds. The article discusses the key differences in the activity of the given subjects in the system and also determines the place of life insurance itself in the system of pension insurance in Ukraine. Practical significance. Having considered the key macroeconomic indicators of Ukraine's economic development, the article predicts the volume of investments into NPFs and insurance premiums for life insurance companies using econometric methods; the benefits and prospects of life insurance are determined. Practical recommendations on the prospects of life insurance development under reforming the pension insurance system in Ukraine are formulated. Value/originality. The modelling of the development of the non-state level of the pension system of Ukraine allowed determining the dynamics of growth of contributions to life insurance companies and contributions to the NPFs in 2017-2020 and drawing a conclusion on the positive prospects for the development of the life insurance market in Ukraine and its special role in the successful reformation of Ukraine's pension system.
\end{abstract}

Key words: pension insurance, pension system, life insurance, voluntary pension insurance, non-state pension funds.

JEL Classification: H55, G22, G23, J26, J32

\section{Introduction}

Under modern conditions of the Ukrainian economy, the system of pension insurance is not only a unique indicator of the perfection of the development of the social area but also the final indicator of the labour contribution of members of society to achieve progress, plays an important role in the financial system of the state, influencing the formation and redistribution of monetary resources in the regional and sectoral aspects.

\footnotetext{
Corresponding author:

${ }^{1}$ Taras Shevchenko National University of Kyiv, Ukraine.

E-mail: pikusruslana3@gmail.com

${ }^{2}$ Taras Shevchenko National University of Kyiv, Ukraine.

E-mail: anna.hem@knu.ua
}

This necessitates the continuous improvement of the pension insurance system in accordance with the needs of society and the real level of economic development of the country. Pension reform in Ukraine should be the first step towards high-quality, equitable social security, as well as the full implementation by the state of its responsibilities to citizens. The experience of developed countries shows that attracting life insurance to retirement plans is an effective way to overcome the 
financial imbalance of the pension insurance system, increase individual responsibility of a citizen in the formation of his own pension protection, achieve social justice in the clear attachment of the amount of pensions received to pre-paid contributions, provision the economy with the long-term financial resources and investment growth of pension assets. The novelty of this article is a forward-looking analysis of the pension insurance system of Ukraine through the development of life insurance, its place and role in the system of pension insurance.

\section{Literature review}

The role of life insurance is studied in the works of such domestic and foreign scientists as V. D. Bazylevych, N. M. Vnukova, O. M. Zalietov, M. V. Kravchenko, Kurt Kral, Lans Bovenberg, Deborah Lucas and others. The key aspects of reforming the pension insurance system of Ukraine are highlighted in the works of such domestic scientists as E. M. Libanova, M. I. Malovanyi, S.A. Melnikov, O. V.Petrushko, M. B. Rippa, V.K. Rudyk, V. S. Tolybyak, G. M. Tretyakova, and others.

However, many challenges to this problem remain unanswered, and existing proposals are controversial or debatable. The complexity and versatility of issues related to the development of the pension insurance system in Ukraine, its reform and the role of life insurance in this process necessitate their further research and are evidence of the relevance of the chosen topic.

\section{Voluntary retirement savings}

In Ukraine, life insurance companies can take a part in the formation of an additional pension for the population of the third-level of the pension system. During his life, the insurer pays contributions to the insurance company and, after surviving to a certain retirement age, receives benefits for a decent living.

The pension system of Ukraine, according to the current legislation, consists of three levels: the first - compulsory solidarity, the second - mandatory accumulation, and the third - voluntary accumulation. Participants in voluntary accumulation are non-state financial institutions, and therefore, non-state pension funds (NPFs) and banks can be at the level of competition among insurance companies that provide life insurance. Banks and NPFs offer a number of savings products, while life insurance companies provide clients (through life insurance policies in its various modifications) not only with the accumulation of funds but also with protection from a number of risks: in case of death or disability of the supporter, his/her family does not remain without funds, which in turn is a solution to the tasks of a social nature. Other differences in the activities of these institutions regarding the offer of savings tools are given in Table 1.

Let's consider more detailed, how the abovementioned role and tasks of life insurance work in developed economies of the world, and above all, how many of these tools and how exactly they are involved in developing the effective pension systems. This will enable formulating the appropriate proposals for Ukrainian realities, as in October 2017 the reform of the pension system is initiated in Ukraine with the Law of Ukraine No. 2148-VIII.

\section{International experience}

An analysis of the current state of life insurance markets in developed countries of the world suggests that life insurance companies are the most powerful financial institutions. Approximately $90 \%$ of the adult population has policies of long-term accumulative life

Table 1

Comparative characteristics of non-state pension insurance by financial intermediaries

\begin{tabular}{|l|l|l|l|}
\hline \multicolumn{1}{|c}{ Criterion } & \multicolumn{1}{c|}{ Non-state pension funds } & \multicolumn{1}{c|}{ Life insurance companies } & \multicolumn{1}{c|}{ Banks } \\
\cline { 2 - 4 } Type of contract & Pension contract / Pension scheme & Pension insurance contract & Deposit pension account \\
\hline $\begin{array}{l}\text { The person in } \\
\text { whose favour the } \\
\text { contributions are paid }\end{array}$ & $\begin{array}{l}\text { A participant of the non-state pension } \\
\text { fund }\end{array}$ & The insured person & The contributor \\
\hline Pension funds & $\begin{array}{l}\text { Amount of commitments in monetary } \\
\text { terms by the pension fund to the } \\
\text { participant }\end{array}$ & $\begin{array}{l}\text { Insurance reserves from pension } \\
\text { insurance contracts }\end{array}$ & Deposits amount \\
\hline $\begin{array}{l}\text { Types of retirement } \\
\text { benefits }\end{array}$ & $\begin{array}{l}\text { - pension for a specified period; } \\
\text { - one-time pension payment. } \\
\text { The participant of the fund, in case of the } \\
\text { choice of a life annuity, concludes the } \\
\text { insurance contract of life insurance pension }\end{array}$ & $\begin{array}{l}\text { (insurance annuity) with guaranteed } \\
\text { period of payment and without; } \\
\text { - one-time pension payment. }\end{array}$ & One-time pension payment \\
\hline Type of guarantee & $\begin{array}{l}\text { Retirement contract as a type of pension } \\
\text { guarantee by entering into a pension } \\
\text { contract with a non-state pension fund }\end{array}$ & $\begin{array}{l}\text { Pension insurance as a type of } \\
\text { pension guarantee by entering into } \\
\text { a pension insurance contract }\end{array}$ & $\begin{array}{l}\text { Pension deposit as a type } \\
\text { of pension guarantee by opening } \\
\text { a pension account at a bank }\end{array}$ \\
\hline
\end{tabular}

Source: compiled by the authors 
insurance. Life insurance, while formally remaining voluntary, is in fact compulsory in the economies of the highly developed countries, as most Americans and Europeans have formed a number of stereotypes, according to which life and health simply cannot be insured. The solvent demand for insurance policies in general and life insurance policies in particular in 2016 (Swiss Re, 2017) can be estimated at 3505 USD per average citizen, including life insurance policies of 1954 USD.

The level of insurance culture in terms of life insurance policies is also increasing in the countries of Eastern Europe and Asia, which are being reformed, especially regarding pension systems. According to the continental distribution of life insurance markets, their global shareholding belongs to insurance companies in Asia - 38.22\%, with a slightly smaller share of European countries - 32.81\%, and North American insurers collect $23.26 \%$ of the world's payments market. The aggregate share of markets in other continents (Latin America, Oceania, and Africa) is only 5.7\% of the world's life insurance (Swiss Re, 2017).

According to the report of the "Swiss Re" International Analytical Centre, in 2016 (Swiss Re, 2017), global insurance market of life insurance collected 2,217 billion dollars of contributions, which is $2.5 \%$ more than in 2015. This growth was lower than in the previous year $-4.4 \%$ but higher than the average figure in 10 years, which is $1.1 \%$. The main sources of growth in life insurance contributions are markets of developing countries, because in 2016, premiums in such countries increased by $17 \%$. An example of such development is the development of life insurance in China, which, thanks to the advent of classical life insurance products, including supplementary pension insurance (due to the reform of the pension system), as well as interest rate liberalization and government efforts to promote increased security of long-term savings, was able to provide $5.7 \%$ of the total increase in life insurance premiums in the world. The development of the life insurance market in Asia is also based on an increase in demand for life insurance products in such countries as India, Indonesia, and Vietnam.

In 2016, the growth rates of life insurance in North America and Western Europe were almost equal. In the United States, small nominal profits are offset by inflation, while in Western Europe downward figures reflect the market response to the introduction of Solvency II. Although overall, the level of collected insurance premiums decreased by $0.5 \%$ to 2,110 billion USD, the high level of life insurance features these countries, because the penetration rate for life insurance varies from $5 \%$ to $10 \%$. For developing countries, this figure does not exceed 3\% (Table 2). It is expected that the economies of developed countries should increase the amount of insurance premiums collected worldwide by a further $50 \%$ in dollar terms by 2021 . It should be noted that in 2016 the markets of leading countries accounted for $81 \%$ of global insurance payments for life insurance (Swiss Re, 2017).

At the same time, the development of life insurance in the world faces many obstacles, including low interest rates, a difficult price environment, and the need to adapt to regulatory changes, including the introduction of Solvency II for European countries, which has created new, tougher conditions for the operation of insurance companies.

In developing countries, the stabilization of economic growth, population growth, urbanization, and the increase in the middle class are the basis of the positive

Table 2

The key indicators of life insurance development in the world in 2016

\begin{tabular}{|c|l|c|c|c|l|c|c|}
\hline No. & Country & $\begin{array}{c}\text { Ratio of life insurance } \\
\text { premiums to } \\
\text { the country's GDP, } \%\end{array}$ & $\begin{array}{c}\text { Insurance } \\
\text { premiums, } \\
\text { million US dollars }\end{array}$ & No. & Country & $\begin{array}{c}\text { Ratio of life insurance } \\
\text { premiums to } \\
\text { the country's GDP, \% }\end{array}$ & $\begin{array}{c}\text { Insurance } \\
\text { premiums, } \\
\text { million US dollars }\end{array}$ \\
\hline 1 & USA & 3.02 & 558847 & 16 & Singapore & 5.48 & 17557 \\
\hline 2 & Japan & 7.15 & 354053 & 17 & Netherlands & 2.13 & 16385 \\
\hline 3 & China & 7.15 & 262616 & 18 & Indonesia & 1.64 & 15299 \\
\hline 4 & UK & 7.58 & 199369 & 19 & Thailand & 3.72 & 15131 \\
\hline 5 & France & 6.06 & 152817 & 20 & Malaysia & 3.15 & 9189 \\
\hline 6 & Italy & 6.23 & 122438 & 21 & Israel & 2.51 & 7997 \\
\hline 7 & South Korea & 7.37 & 104169 & 22 & Portugal & 3.59 & 7446 \\
\hline 8 & Germany & 2.75 & 94661 & 23 & Poland & 0.99 & 4664 \\
\hline 9 & India & 2.72 & 61817 & 24 & UAE & 0.69 & 2448 \\
\hline 10 & Canada & 3.27 & 49976 & 25 & Vietnam & 1 & 2053 \\
\hline 11 & Australia & 2.99 & 37692 & 26 & Greece & 1.01 & 1971 \\
\hline 12 & Spain & 2.8 & 34459 & 27 & Turkey & 0.19 & 1644 \\
\hline 13 & Switzerland & 4.72 & 31151 & 28 & Croatia & 0.86 & 429 \\
\hline 14 & Finland & 9.53 & 22620 & 29 & Kazakhstan & 0.12 & 163 \\
\hline 15 & Denmark & 6.95 & 21327 & 30 & Ukraine & 0.13 & 113 \\
\hline
\end{tabular}

Source: compiled by the authors using (Swiss Re, 2017) 
prediction of penetration into the life insurance field. In a broader sense, changes in demography, medicine, and technology can affect mortality and morbidity in many parts of the world, increasing the fundamental impact on life insurance.

The experience of developed countries shows that life insurance plays a significant role in shaping pension plans for future pensioners at the level of the non-state pension system. In turn, non-state pensions, in particular, through life insurance instruments, play a significant role in about half of the countries of the Organization for Economic Cooperation and Development (OECD). Thus, in 2016, for pension systems in the OECD countries, the average gross replacement rate for state pensions was $41 \%$, while for non-state actors - 53\%. When including the nonstate voluntary pension insurance, the average indicator for OECD increases to 59\%. For eight OECD countries (Belgium, Germany, UK, Ireland, USA, Canada, Japan, and New Zealand), where voluntary non-state pensions are spread, and the average replacement rate is $63 \%$ for the average recipient, who wants to pay voluntarily, compared with $37 \%$, when only mandatory accumulation is considered (OECD, 2017).

Defining the place of life insurance in pension systems of European countries, the experience of Spain and Great Britain is sufficiently indicative for Ukraine.

Spain's experience is important for Ukraine since its economy is at the stage of rebuilding after the debt crisis in Europe and depends directly on the policy of cooperation with creditors (IMF). It should be noted that in 2016 Spain collected $21.5 \%$ more life insurance contributions than in 2015, which in cash amounts to 7 million euro. Over the past 5 years, this indicator has grown by $7.87 \%$ (OECD, 2017), which was primarily due to an increase in contributions from retirement savings products and is a clear indication of the positive dynamics of the life insurance market, in general, the insurance market and the country's economy.

At the present stage of market transformation, Spain has a three-level pension system consisting of dominant state pension plans (analogous to the solidarity pension system of Ukraine), voluntary professional and private pension savings. The reform of the pension system in Spain was carried out in 2011. There has been an increase in the retirement age from 65 to 67 years, as well as an increase in the number of years of payment of insurance premiums necessary for a full pension from 15 to 25 years. These changes began to be implemented gradually from 2013 and their full implementation is expected until 2027. Currently, pension payments in this country are formed at the expense of workers' contributions $-4.7 \%$ and employers' - 23.6\%. In December 2013, according to the reform plans, the "sustainability ratio" began to work, which linked the initial pension with changes in the expected life expectancy and changed the procedure for indexing public pensions under the state pension plan. Starting from 2019, the sustainability rate will be based on the life expectancy after reaching the retirement age during 5 years. This ratio will only be applied once during the appointment of pensions and will be reviewed every 5 years. It is projected that the size of initial pensions may be reduced by 5 percent, on average, every 10 years. Also in 2013, a new indexation method was introduced, according to which pensions are adjusted on the basis of the ratio of contributions to the pension system to expenditures over the past 5 years and the forecast for the next 5 years. According to the National Institute of Social Insurance estimates, the new adjustment method will allow Spain to save 33 billion euro ( 45.5 billion USD) by 2022 .

Such savings methods should enable the state pension system to balance the contributions and disbursements in the short and long run.

The non-state voluntary pension system of Spain, which began to develop rapidly after the pension reform, is presented in the form of pension plans, which are provided by pension funds and insurance companies that provide life insurance. Spanish legislation stipulates that life insurance companies may be subject to pension fund management. By the beginning of 2016, out of 82 authorized management companies, 47 were life insurance companies representing $57.3 \%$ of the market, and which account for $33 \%$ of the total assets of pension funds (IMF, 2016).

The positive dynamics of the development of the nonstate voluntary level of the pension system can also be explained by the tax benefits that feature the Spanish law. Contributions to private pension plans can be deducted from taxable income up to the specified annual limits, which today are:

- EUR 10000 - for taxpayers under the age of 50;

- EUR 12500 - for taxpayers over the age of 50.

The legislation also establishes a limit of $30 \%$ of the taxpayer's income for the tax year in question ( $50 \%$ for persons over 50 years of age). Such limits are applied annually during the calendar year. The taxpayer may save the maximum marginal tax rate, which in 2017 accounted for $43 \%$. Also, additional contributions of up to 2000 euro can be made to the spouses' pension plans, which are taxed from 0 to 8000 euro. For people with disabilities, these limits are higher and set at 24250 euro (Advoco, 2017). Direct relatives can contribute up to 10000 euro to retirement plans for people with disabilities.

Consequently, the reform of the Spanish pension system and the experience of using life insurance are relevant to the Ukrainian practice of reforming the pension system and can be used in the following part:

- increase in retirement age is a prerequisite for the reform of the state component of the pension system for its further effective functioning;

- life insurance companies, being the experienced financial market participants, can provide pension management services based on insurance policies both to individual enterprises, as well as NPFs; 
- tax incentives are a driving tool for the development of a non-state voluntary sector of the pension system (third level of the pension system of Ukraine), which increases the motivation for participation in this system for both the employer and the worker or selfemployed person. Individual conditions for taxation of participation in the pension system may be offered to people with disabilities.

The UK economy is one of the world's leading with the branched financial system and a wide range of services, so the experience of using life insurance under the reform of the country's pension system is indicative.

The UK is the fourth largest country in the world (after the USA, Japan, and China) and the first in Europe to develop the life insurance market and collects per year 65 million USD more than France, which is in the next position (Table 2). Despite the fact that the country had a small downward trend in life insurance contributions collected in 2016 , they increased by $13 \%$ over the past 5 years (Swiss Re, 2017).

The pension reform, which took place in the United Kingdom in several stages, began in 2009, triggered dramatic changes in the country's pension system in 2014, when the transition from a two-level state pension system to a one-level system was legislated. Since April 2016, a new state pension system has entered into force, which introduced a single-rate state pension with a fixed rate for workers who retire after April 6, 2016. A full new state pension in the country can be obtained with 35 qualifying years of work experience and is based on insurance premiums to the National Insurance Fund. However, this system does not apply to pensioners who retired earlier than the specified date, for them the state pension is paid according to the old rules. Such pensioners have the opportunity to receive a basic pension from the state, subject to the availability of 30 qualifying years, as well as an additional pension if they also contributed money under a special state pension plan that provided the second level of the state pension system. The basic pension is indexed each year, depending on the consumer price index.

Consequently, there are three types of pensions in the country and, accordingly, three ways of receiving them: - state pension (for the registration of this type of pension, it is necessary to transfer a fixed amount monthly to the Pension Insurance Fund for at least ten years);

- labour pension (employer pension plans);

- personal/private pension (personal savings of citizens).

The reform will also increase the retirement age of 65 for men and 63 for women up to 66 years of age (from 2018 to 2020) and 67 years (from 2026 to 2028) for the citizens of both sexes. At the same time, the system of motivation for late retirement is working: for every 9 weeks, for which the pensioner has decided to postpone his retirement, the payment of the state pension will increase by $1 \%$, i.e. by $5.8 \%$ per year ( 5 weeks and $10.4 \%$ per year under the old system).

Since April 2015, the flexibility of the population's access to own pension savings has been increased, which gave the right to choose the way to receive pension benefits - in the form of a lump sum, payments for a certain time or the purchase of an annuity.

The pension reform also applies to labour pensions and provides that all employers are required to automatically credit employees to their company's qualified pension plan or to the NEST State Pension Plan and make contributions on their behalf. Enrolment is automatic for all workers, but unlike the employer, they have the right to refuse such participation (SSA, 2017).

For labour pensions, there are two tools available: insurance schemes offered by life insurance companies and retirement plans created for self-government by the employer. Insurance schemes are mechanisms that are provided directly by insurance companies, where the benefits provided are covered by one or more insurance contracts or annuity contracts. After retirement, the worker has the right to withdraw up to $25 \%$ of retirement savings once. This amount will be exempt from taxes. The remaining payments will be made proportionally and subject to income tax (SSA, 2017).

For the purpose of providing a private pension in the UK, the so-called personal pension plans are an agreement that an employee can individually set up with an external supplier - an insurance company, an insurance agent or a broker. The credibility of this type of savings is evidenced by the ever-increasing amount of contributions and retirement benefits made by life insurance companies. Thus, the total UK long-term pension payments in 2016 (Statista, 2016) amounted to 122728 billion pounds, which is by $3.2 \%$ more than during the previous period. The overall trend of payments over the past ten years is positive. The average growth is around $7 \%$ per year.

Consequently, the experience of the UK regarding the role of life insurance companies in the country's pension system is indicative for Ukraine, which is at the stage of reforming the pension system. Thus, insurance companies may not only participate in non-state voluntary insurance but also take a definite place in the introduction of the second level of the pension system, which will be mandatory for employers and workers. The availability of reliable tools for long-term savings, the fight against informal employment, and the motivation to legalize income can be provided with insurance products that offer life insurance companies and tax incentives for their consumers. Also, the UK experience can be implemented in Ukrainian pension legislation in terms of financial incentives for late retirement and the need to increase the retirement age of the population.

Accordingly, it can be concluded that life insurance in the developed world markets and emerging markets has a significant socio-economic value for the economies 
of these countries. The high growth of the insurance industry as a whole, and life insurance in particular, is an indicator of the effective development of the financial sector of these countries.

The experience of developed countries shows how important is life insurance in pension systems in these countries. Thanks to the implementation of foreign experience (countries such as Spain and the UK) into the Ukrainian pension system, we can talk about the relevance and prospects of life insurance as an effective tool for long-term retirement savings. In particular, obstacles such as the mentality of the population, distrust and stereotypes regarding insurance products, the imperfection of the management apparatus, high inflationary risks, and low incomes of the population may arise in the path of reforming the pension system as a whole and the development of life insurance in particular.

One of the main problems is the solvent demand for non-state pension insurance in general and insurance products in the field of life insurance, the solution of which in the future will depend on the success of the functioning of both the second and third levels of the pension system in Ukraine.

\section{Prospects for the development of life insurance in Ukraine}

At the current stage of market transformation in Ukraine, the demand for non-state pension system services and savings tools is quite low, which is explained by the low purchasing power of the population. In general, only $1.5 \%-2 \%$ of GDP is redistributed through the insurance industry in Ukraine, while in developed countries this figure ranges from $6 \%$ to $12 \%$ (Swiss Re, 2017).

The Ukrainian insurance market is at an early stage of development but has a great potential. In 2016, the gross insurance premiums collected by life insurance companies more than doubled their respective volumes in 2011, while insurance premiums grew by $17 \%$ compared to 2011 (NFP, 2011-2017).

The Government of Ukraine provides for the active implementation of economic and social reforms, as identified in the medium-term plan of priority actions (KMU, 2017). Accordingly, in this scenario, in 2018, GDP growth is projected at 3\%, in 2019 - by $3.6 \%$, in 2020 - by $4 \%$. The consumer price index (December to December of the previous year) is projected at $107 \%$ in $2018,105.9 \%$ in 2019 , and $105 \%$ in 2020 .

One of the most important tasks of the pension reform in Ukraine is to stimulate the development of the non-state level of the pension system in order to preserve pension savings and further invest them in the Ukrainian economy.

In order to determine the prospects for the development of life insurance in Ukraine at the reform stage, we have modelled the forecast for the development of this type of insurance as a part of the pension system of Ukraine.

In the scientific work, the basic models of econometric analysis are used, such as: polynomial model, ARMA and ARIMA models.

As a statistical basis, the time period of 10 years from 2006 to 2016 was chosen. It is planned to build a forecast from 2017 to 2020 .

The main indicators of the country's economic development, which influence the degree of development of the non-state level of the pension system of Ukraine, were selected as follows:

- the volume of GDP, since GDP is one of the main macroeconomic indicators of the economic development of any country - GDP;

- the total amount of incomes - INCOME, and savings of the population of Ukraine - SAVINGS;

- the amount of pension contributions to the NPF PENSION;

- insurance contributions to life insurance companies LIFE-INS.

These indicators describe the level of incomes of the population and the part, which can be invested in voluntary pension accumulation and life insurance.

Features of the main macroeconomic indicators of Ukraine's economic development from 2006 to 2016 are presented in Table 3.

The process of forecasting the development of the non-state level of the pension system of Ukraine is based on an algorithm that involves the construction of four econometric models.

Forecasting the volume of investments into NPFs and insurance premiums into life insurance companies consists of the following stages:

1. The linear model of the dependence of the population's income on the GDP growth rate.

2. ARMA model of type $(0,1)$ of the volume of savings depending on the volume of GDP and household income.

3. ARMA model of type $(0,1)$ of the amount of insurance premiums depending on the volume of income and savings of the population.

4. ARIMA model of type $(1,1,1)$ of pension funds' contributions to NPF depending on the volume of income and savings of the population.

The following econometric models are constructed using the macroeconomic indicators of the development of the pension system of Ukraine and in accordance with the defined modelling algorithm:

1. The linear model of the dependence of the income of the population on the volume of GDP, in the form of HOUSEHOLD_INCOME $=0.896428^{*} \mathrm{GDP}+33356.67$.

2. ARMA model of type $(0,1)$ of the changes in volumes of savings depending on GDP growth rates and household incomes, in the form: SAVINGS = 0.490318 * HOUSEHOLD_INCOME -0.446560 * $\operatorname{GDP}[\mathrm{MA}(1)=0.458471]+\overline{6} 65753.37$. 
3. ARMA model of type (0.1) of the growth rate of insurance premiums depending on the growth rates of income and changes in volumes of savings, in the form: LIFE INS $=0.001496 *$ HOUSEHOLD INCOME $+0.006673^{*}$ SAVINGS [MA $\left.(1)=0.876809\right]-219.4848$.

4. ARIMA model of type $(1,1,1)$ of the growth rate of pension contributions to the NPF depending on the growth rate of household income and changes in the volume of savings, in the form: PENSION $=-0.000152$ * * HOUSEHOLD INCOME + 0.000345 * SAVINGS $[\operatorname{AR}(1)=-0.5666 \overline{64} \mathrm{MA}(1)=3.025943]+369.1841$.

The assessment of the quality of the constructed models was performed using the following criteria (Table 4):
- AdjustedRsquared criterion (more than 0.5) - to test the quality of the model;

- DurbinWatsonStst criterion - for the auto-correlation test;

- Prob. (F-stat) criterion (less than 0.05) - to check the adequacy of the model and its significance;

- M.A.P.E. criterion (8-15\%) - to check the quality of the forecast.

According to the results of econometric modelling, the projected volume of Ukrainian population's incomes in 2018 will amount to 2,203,324 million UAH, and in 2019 - to $2,280,450$ million UAH, which is $3.5 \%$ more than in 2018. According to the projected figures,

Table 3

Key macroeconomic indicators of development of the economy of Ukraine, 2006-2016

\begin{tabular}{|c|c|c|c|c|c|c|}
\hline Year & $\begin{array}{c}\text { Dynamics of } \\
\text { average monthly } \\
\text { salary, (UAH) }\end{array}$ & $\begin{array}{c}\text { Household } \\
\text { incomes, } \\
\text { (million UAH) }\end{array}$ & $\begin{array}{c}\text { Savings, } \\
\text { (million UAH) }\end{array}$ & $\begin{array}{c}\text { GDP, } \\
\text { (million UAH) }\end{array}$ & $\begin{array}{c}\text { Contributions to } \\
\text { insurance companies, } \\
\text { (million UAH) }\end{array}$ & $\begin{array}{c}\text { Contributions } \\
\text { to NPFs, } \\
\text { (million UAH) }\end{array}$ \\
\hline 2006 & 1041 & 472061 & 37044 & 565018 & 608 & 120 \\
\hline 2007 & 1351 & 623289 & 37840 & 751106 & 991 & 234 \\
\hline 2008 & 1806 & 845641 & 22496 & 990819 & 1609 & 583 \\
\hline 2009 & 1906 & 894286 & 69884 & 947042 & 1789 & 755 \\
\hline 2010 & 2239 & 1101175 & 142289 & 1120585 & 2185 & 925 \\
\hline 2011 & 2633 & 1266753 & 123123 & 1349178 & 2664 & 1102 \\
\hline 2012 & 3026 & 1457864 & 147280 & 1459096 & 3222 & 1314 \\
\hline 2013 & 3282 & 1548733 & 116266 & 1522657 & 2476 & 1588 \\
\hline 2014 & 3480 & 1516768 & 83320 & 1586915 & 2160 & 1808 \\
\hline 2015 & 4195 & 1743979 & 6200 & 1988544 & 2186.60 & 1886.80 \\
\hline 2016 & 5183 & 1989771 & -18400 & 2385367 & 2756.10 & 1895 \\
\hline
\end{tabular}

Source: developed by authors using (Ukrstat, 2006-2016)

Table 4

Characteristics of the econometric analysis models

\begin{tabular}{|c|c|c|c|c|}
\hline No. & Model & Equation & Model Characteristics & Forecast for 2020 \\
\hline 1 & $\begin{array}{l}\text { The linear model of the } \\
\text { dependence of population } \\
\text { income on the GDP growth } \\
\text { rate }\end{array}$ & $\begin{array}{l}\text { HOUSEHOLD_INCOME } \\
=0.896428^{*} \mathrm{GDP}+ \\
33356.67\end{array}$ & $\begin{array}{l}\text { Determination coefficient R2 }=0.985623 \text {, } \\
\text { indicating a very close linear relationship. } \\
\text { The value of Prob. (F-statistics) }=0,00000 \text {, } \\
\text { so the model is adequate both at the level of } \\
\text { significance } 0.05 \text {, and at the level of } 0.01 \text {. }\end{array}$ & $\begin{array}{l}\text { Increase in income by } \\
19 \% \text {, forecasted figure } \\
\text { for } 2020 \text { is } 2,369,221 \\
\text { mln. UAH }\end{array}$ \\
\hline 2 & $\begin{array}{l}\text { ARMA model of type }(0,1) \\
\text { of the changes in volumes of } \\
\text { savings depending on GDP } \\
\text { growth rates and household } \\
\text { incomes }\end{array}$ & $\begin{array}{l}\text { SAVINGS }=0.490318^{*} \\
\text { HOUSEHOLD_INCOME } \\
-0.446560^{*} \text { GDP }[\mathrm{MA}(1)= \\
0.458471]+65753.37\end{array}$ & $\begin{array}{l}\text { Determination coefficient R2 }=0.864671 \text {, } \\
\text { indicating a very close linear relationship. } \\
\text { The value of Prob. (F-statistics) }=0.002008 \text {, } \\
\text { so the model is adequate both at the level of } \\
\text { significance } 0.05 \text { and at the level of } 0.01 \text {. }\end{array}$ & $\begin{array}{l}\text { Reducing savings by } \\
9.2 \% \text {, the forecasted } \\
\text { figure for } 2020 \text { is } 57 \\
167,69 \mathrm{mln} \text {. UAH }\end{array}$ \\
\hline 3 & $\begin{array}{l}\text { ARMA model of type }(0,1) \text { of } \\
\text { the growth rate of insurance } \\
\text { premiums depending on the } \\
\text { growth rates of income and } \\
\text { changes in volumes of savings }\end{array}$ & $\begin{array}{l}\text { LIFE_INS }==0.001496^{*} \\
\text { HOUSEHOLD_INCOME } \\
++0.006673^{*} \text { SAVINGS } \\
{[\mathrm{MA}(1)=0.876809]-} \\
219.4848\end{array}$ & $\begin{array}{l}\text { Determination coefficient R2 }=0.912432 \text {, } \\
\text { indicating a very close linear relationship. } \\
\text { The value of Prob. (F-statistics) }=0.000447 \text {, } \\
\text { so the model is adequate both at the level of } \\
\text { significance } 0.05 \text { and at the level of } 0.01 \text {. }\end{array}$ & $\begin{array}{l}\text { Increase in insurance } \\
\text { premiums by } 18.2 \% \text {, } \\
\text { the forecasted figure } \\
\text { for } 2020 \text { is } 3920.58 \\
\text { mln. UAH }\end{array}$ \\
\hline 4 & $\begin{array}{l}\text { ARIMA model of type } \\
(1,1,1) \text { of the growth rate } \\
\text { of pension contributions to } \\
\text { the NPF depending on the } \\
\text { growth rate of household } \\
\text { income and changes in the } \\
\text { volume of savings }\end{array}$ & $\begin{array}{l}\text { PENSION }=-0.000152 * \\
{ }^{*} \text { HOUSEHOLD_ } \\
\text { INCOME }+ \\
+0.000345^{*} \text { SAVINGS } \\
{[\text { AR }(1)=-0.566664} \\
\text { MA }(1)=3.025943]+369.1841\end{array}$ & $\begin{array}{l}\text { Determination coefficient R2 }=0.947282 \text {, } \\
\text { indicating a very close linear relationship. } \\
\text { The value of Prob. (F-statistics) }=0.008044 \text {, } \\
\text { so the model is adequate both at the level of } \\
\text { significance } 0.05 \text { and at the level of } 0.01 \text {. }\end{array}$ & $\begin{array}{l}\text { Increase in the } \\
\text { amount of pension } \\
\text { contributions by } \\
4.2 \% \text {, the forecasted } \\
\text { figure for } 2020 \text { is } \\
2887.23 \mathrm{mln} \text {. UAH }\end{array}$ \\
\hline
\end{tabular}

Source: developed by the authors 
the income of the population in 2020 will be $2,369,221$ million UAH, which is $19 \%$ more than in 2016.

The projected increase in household incomes in future periods can actively affect the level of population accumulation, the increase in the contribution activity to non-state pension funds and life insurance companies.

The key factors influencing the saving activity of the population are (Zaletov, 2006):

- expectations about the dynamics of prices and quantity of goods in the market;

- expectations of changes in the volume of income and financial position in the future;

- interest rates on loans and deposits;

- tax rates, as the increase in tax rates reduces the income of end-use and, as a consequence, reduces the consumption and savings;

- development of the system of state social insurance; - development of capital markets, as they perform a dual function of stimulating savings and loans;

- demographic factors: age, gender, social status, education of the person who decides on the type of financial behaviour in general;

- level of corruption in the country;

- trust in financial institutions and the availability of convenient investment instruments.

To date, in Ukraine, only the banking sector has privileges among the financial institutions that provide long-term savings. There is a fund for guaranteeing deposits of individuals only for banking institutions, which in turn makes a life insurance company less competitive. In conditions of high level of mistrust of the population, unformed insurance culture and certain mental features, it is necessary to provide guarantees and broad rights to protect the insurer's deposits and the investment income in life insurance, as this is one of the key factors in stimulating the placement of savings in the life insurance segment.

According to the results of the model of population saving forecasting, there is a slight decrease. In 2020, the volume will be about 57,167.59 million UAH, which is $9.3 \%$ less compared to 2017 . This phenomenon can be explained by an increase in consumption and rising prices due to the devaluation of the hryvnia, because despite the increase in household incomes, the cost of living increases, which does not allow saving enough money that could be used to invest in the real economy or pension insurance.

Despite the declining dynamics of savings, the modelling results show that contributions to life insurance companies in 2018 will amount to $3,517.93$ million UAH, which is $6.04 \%$ more than in $2017(3,316.604$ million UAH). Estimates in 2020 should increase by $5.4 \%$ compared to 2019 .

Given the social significance of life insurance, as well as the inherent investment in this area, a strong legislative framework is essential for its sustainable development and growth stimulation. In this issue, the experience of developed countries of the world can be drawn.
The nearest priorities in regulating the life insurance market in Ukraine should be: introduction of European principles of regulation of insurance activity; ensuring transparency of the insurance market by publishing reliable and regular financial statements; the struggle for the purity of the insurance market, by raising standards and increasing the responsibility for the failure to comply.

According to the results of the modelling, the amount of pension contributions to the NPF will be 2,516.38 million $\mathrm{UAH}$ in 2018, 2,703.024 million UAH in 2019, and $2,887.23$ million UAH in 2020. The actual state of payments to the non-state pension system of Ukraine in part of the contributions to non-state pension funds is characterized by a slow increase in growth rates over the past 5 years. Contributionstolifeinsurance companies haveasignificantly higher gain and more powered dynamics. There is a passive increase in contributions to non-state pension funds with an active growth of contributions to life insurance companies, which features the overall improvement of the climate in the life insurance market in Ukraine.

According to the results of 2016, the amount of pension contributions to life insurance companies was $45.4 \%$ higher than to non-state pension funds, which confirms the effectiveness of life insurance companies and their benefits over non-state pension funds (Figure 1).

According to the results of 2017, the amount of pension contributions to life insurance companies was $45.4 \%$ higher than to non-state pension funds, which confirms the effectiveness of life insurance companies and their benefits over non-state pension funds (Figure 1).

Consequently, modelling of the development of the non-state level of the pension system of Ukraine is of high quality since all models met the limits of the abovementioned criteria.

The analysis showed that the positive dynamics of the growth of pension contributions to life insurance companies and non-state pension funds will be maintained in Ukraine during 2018-2020. Life insurance has a high growth dynamic, which is a good indicator of the efficiency of the non-state pension insurance sector in Ukraine.

\section{Conclusions}

1. Life insurance is an insurance that provides for the protection of property interests due to the death of the insured since the key feature is the fact that human life has no unambiguous approach to its value (monetary) assessment. Under this type of insurance, it is impossible to accurately determine the amount of damage caused by the onset of the insured event. The main feature of life insurance is a combination of insurance protection and savings. On the one hand, life insurance is a tool that allows the state, both at macro and micro level, to increase the efficiency of financing social risks and removing the corresponding burden from the state budget, and on the other - it creates a powerful national investor. 


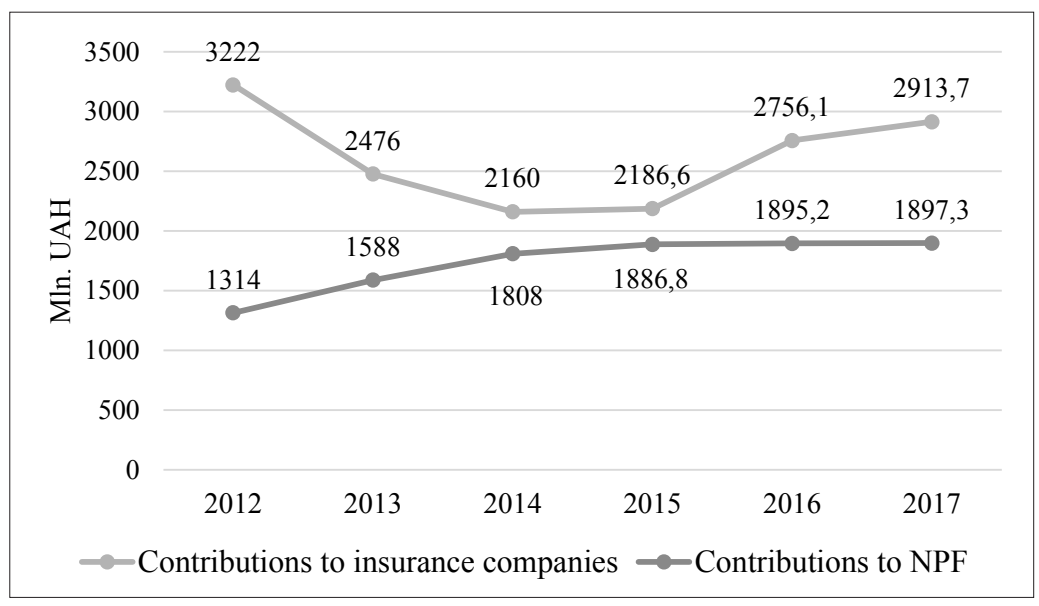

Figure 1. Amount of contributions to life insurance companies

and non-state pension funds in Ukraine from 2012 to 2016, $\mathrm{mln}$. UAH

2. International experience of many countries of the world shows that life insurance is a powerful tool for the socio-economic development of society, both for developed countries and for developing countries. Effective development of the insurance industry and life insurance as a sub-sector reveals the highest level of development of the financial sector of the country; therefore, life insurance is one of the central types of the insurance market and of great socio-economic importance in all developed countries.

3. The experience of developed European countries (Spain, Great Britain) in reforming pension systems can be used in determining the directions of the implementation of pension reform in Ukraine and points to the need to involve life insurance companies in the development of the second and third levels of the pension system.

4. The key directions of implementation of international experience in reforming the pension system of Ukraine are:

- increasing the retirement age, which is a prerequisite for the reform of the state component of the pension system for its further effective functioning;

- increasing the pension insurance record for a labour pool of the population, which was done in Ukraine in October 2017 (Swiss Re, 2017), is a sound and wellconsidered decision inherent in pension reform in most foreign countries;

- the financial motivation of late retirement as a tool for an indirect increase of retirement age;
- involvement of life insurance companies in managing retirement plans as at separate enterprises, as well as in $\mathrm{NPF}$ as a whole;

- changes in tax legislation regarding tax exemptions for consumer savings products offered by life insurance companies, as well as for people with disabilities;

- involvement of life insurance companies in the functioning of the second level of the pension system, which, after a possible introduction in 2019, will become compulsory for employers and workers.

5. The modelling of the development of the nonstate level of the pension system of Ukraine allowed determining the dynamics of growth of contributions to life insurance companies and contributions to the NPFs in 2017-2020, and drawing a conclusion on the positive prospects for the development of the life insurance market in Ukraine and its special role in the successful reformation of Ukraine's pension system.

6. The following ways of attracting life insurance to reforming the pension system in Ukraine should be considered as promising for Ukraine, as well as for further research:

- creation of favourable conditions for the development of life insurance as a tool for long-term pension accumulation at the third level of the pension system by improving reliability and establishment of certain guarantee funds; - involvement of life insurance companies in the implementation of the second level of the pension system, which will give the right to choose an instrument of accumulation for the society and minimize the risk of nationalization of accumulated funds.

\section{References:}

Advoco (2018). Tax treatment of private pensions in Spain. Retrieved April 17, 2018, from: http://www.advoco.es/ advice/14-health-a-social-security/90-tax-treatment-of-private-pensions-in-spain.html

Bovenberg, Lans, \& Nijman, Theo (2017). Personal pensions with risk sharing. Journal of Pension Economics and Finance, 16, 450-466.

Cabinet of Ministers of Ukraine (2017). Order "On approval of the medium-term plan of the Government's priority actions by 2020" No. 275-p of 03 April 2017. Retrieved from: https://www.kmu.gov.ua/ua/npas/249935442 
Ljutyi, I. O., Borynecj, S. Ja., Varnalij Z. S. and other (2017). Pensijne strakhuvannja [Pension insurance]. Finansy [Finances]. Kyiv: Lira-K, pp. 422-437.

International Monetary Fund (2017). Spain. Financial sector assessment program technical note-insurance sector supervision and regulation. Retrieved April 15, 2018, from: http://www.imf.org/en/Countries/ESP

Lucas, Deborah (2015). Joint risk of DB pension underfunding and sponsor termination: incorporating option-based projections and valuations into PIMS. Journal of Pension Economics and Finance, 14, 172-185.

OECD (2017), Pensions at a Glance 2017: OECD and G20 indicators, OECD Publishing, Paris. DOI: http://dx.doi.org/ 10.1787 /pension_glance-2017-13-en

Overview of Financial Services Markets (2011/2017). National Commission for Regulation of Financial Services Markets in Ukraine, Retrieved April 17, 2018, from: https://www.nfp.gov.ua/ua/Informatsiia-pro-stan-i-rozvytokstrakhovoho-rynku-Ukrainy.html

Petrushka, O. V. (2015). Dosvid reformuvannja pensijnykh system zarubizhnykh krajin ta jogho vykorystannja v Ukrajini [The experience of reforming pension systems of foreign countries and their use in Ukraine]. Science and Economics, 1, 19-27.

Pikus, R. V., Prikazyuk, N. V., Berezina, S. B., \& Tretyak, D. D. (2018). Social Insurance: Textbook, Komprynt, Kyiv, $197 \mathrm{p}$.

Prikazjuk, N. V. (2015). Tendenciji ta perspektyvy rozvytku pensijnoji systemy Ukrajiny [Trends and Prospects for the Development of the Pension System of Ukraine]. Global and national problems of the economy, 7, 731-737.

State Statistics Service of Ukraine [online], Retrieved April 17, 2018, from: http://www.ukrstat.gov.ua/operativ/ operativ2017/gdn/dvn/dvn_u/dvn0317_u.ht

Statista (2017). Premiums of long-term insurance companies in the United Kingdom (UK) from 1st quarter 2014 to 3rd quarter 2017 (in billion GBP). Retrieved April 15, 2018, from: https://www.statista.com/statistics/293975/ uk-insurance-market-premiums-of-long-term-insurance-companies/

Swiss Re (2017). World insurance in 2016: the China growth engine steams ahead. Retrieved April 12, 2018, from: http://media.swissre.com/documents/sigma3_2017_en.pdf.

The United States Social Security Administration (2016). Social Security Programs Throughout the World: Europe, 2016. Retrieved April 12, 2018, from: https://www.ssa.gov/policy/docs/progdesc/ssptw/2016-2017/europe/ united-kingdom.html

Tolubjak, V. S. (2014). Pensijni reformy v zarubizhnykh krajinakh: osoblyvosti ta rezuljtaty [Pension Reforms in Foreign Countries: Peculiarities and Results]. Scientific Bulletin of Kherson State University, Series of Economic Sciences, 9(5), 201-213.

Verkhovna Rada of Ukraine (2003) Law of Ukraine "Non-Governmental Pension Provision" Resolution No. 1057-IV of 09 July 2003. Retrieved from: http:// zakon5.rada.gov.ua/laws/show/1057-15

Verkhovna Rada of Ukraine (2003). Law of Ukraine "Compulsory Governmental Pension Insurance", Resolution No. 1058-IV of 09 July 2003. Retrieved from: http://zakon4.rada.gov.ua/laws/show/1058-15

Verkhovna Rada of Ukraine (2018). Draft Law of Ukraine "On Amendments to Certain Legislative Acts of Ukraine on the Introduction of the Cumulative System of Mandatory State Pension Insurance" No. 6677. Retrieved from: http://w1.c1.rada.gov.ua/pls/zweb2/webproc4_1?pf3511=62218

Zaletov, O. M. (2006). Ubezpechennja zhyttja: monoghrafija [Life insurance: monograph]. Kyiv: International Agency "Bison". 